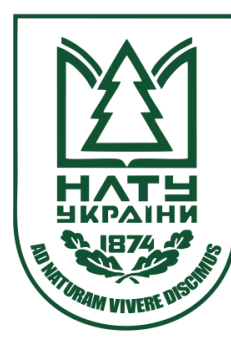

Науковий вісник НлтУ України

Scientific Bulletin of UNFU

https://nv.nltu.edu.ua

https://doi.org/10.15421/40280725

$@ \bowtie$ Correspondence author

Article received 15.07.2018 p.

Article accepted 26.09.2018 p.

A. I. Sydor

удк 004.383.3

andrij9997@ukr.net

A. I. Сидор

Тернопільський національний економічний університет, м. Тернопіль, Україна

\title{
МЕТОД РОЗПІЗНАВАННЯ ДОРОЖНІХ ЗНАКІВ НА ОСНОВІ ОЦІНОК ХЕММІНГОВОЇ ВІДДАЛІ ТА СТРУКТУРНОЇ СКЛАДНОСТІ
}

Проаналізовано основні принципи роботи систем розпізнавання дорожніх знаків відомих виробників. Описано алгоритм роботи та основні компоненти пристрою визначення елементів, зображених на дорожньому знаку. Запропоновано метод розпізнавання дорожніх знаків на основі оцінки Хеммінгової віддалі. Проведено аналіз дорожніх знаків категорії наказові знаки. Здійснено розбиття цієї категорії на менші підкатегорії для інформативного аналізу зображень. Виділено основні елементи наказових знаків, на основі яких запропоновано принципи кодування кожного знаку цієї категорії. Розраховано структурну складність зображень дорожніх знаків категорії наказові знаки. Наведено таблицю значень оцінок Хеммінгової віддалі для різних пар знаків запропонованих підкатегорій, на основі яких побудовано діаграми розподілу значень оцінок Хеммінгової віддалі. Проведено аналіз дорожніх знаків категорії заборонні знаки. Для цієї категорії відділено підкатегорії, запропоновано принцип кодування знаків, який базується на інформативних ознаках зображених елементів, побудовано діаграми розподілу значень отриманих оцінок Хеммінгової віддалі. Для розглянутих категорій знаків обчислено максимальні та мінімальні значення Хеммінгової віддалі. Запропоновано оцінку інформативності дорожніх знаків, на основі відношення Хеммінгової віддалі до структурної складності. Побудовано графіки, які ілюструють інформативність розглянутих знаків кожної підкатегорії. Зроблено висновки та рекомендації щодо удосконалення дорожніх знаків на основі оцінки Хеммінгової віддалі.

Ключові слова: оцінка інформативності; системи розпізнавання; структурна ідентифікація; кодування.

Вступ. Успішний розвиток інформаційних та комп'ютерних систем, програмних та апаратних засобів реалізації складних алгоритмів опрацювання даних створює сприятливі умови успішного вирішення широкого класу задач розпізнавання образів у промисловості, медицині, навігації, моніторингу та захисту природних ресурсів та ін.

3 огляду на збільшення числа та динаміки потоків транспортних засобів стає актуальною задача автоматичного розпізнавання дорожніх знаків для зменшення числа ДТП, забруднення середовища, особливо в разі виникнення завад сприйняття та правильного розпізнавання знаків в умовах туману, дощу, пилу та ін.

Відомі системи розпізнавання дорожніх знаків призначені для нагадування водіям транспортних засобів про дотримання правил дорожнього руху (Sydor, 2018). Через складність реалізації і чималу кількість дорожніх знаків, сучасні системи розпізнавання знаків працюють лише з обмеженою кількістю знаків, передусім це знаки обмеження швидкісного режиму. Більшість систем розпізнає тільки знак обмеження швидкості й знак кінця обмеження швидкості (Sehin, 2013). Якщо швидкість автомобіля перевищує дозволену, система подає сигнал про необхідність зменшити швидкість. Деякі найсучасніші модифіковані системи дають змогу також розпізнати знаки заборони обгону (Sehin, 2013).

Розробкою системи розпізнавання образів зазвичай розробляють найбільші виробники автомобілів: Traffic Sign Recognition; Speed Limit Assist; Lane Departure Warning; Mercedes-Benz S-Class; Opel Eye (Sydor, 2018). Стандартно систему розпізнавання образів позначають абревіатурою RSR (Road Sign Recognition).

Незважаючи на різні назви, комп'ютерні пристрої, які реалізують розпізнавання дорожніх знаків, принцип роботи для зазначених систем істотно не відрізняється. До складу обчислення системи розпізнавання дорожніх знаків входять: відеокамера, електронний блок керування, монітор для виводу інформації, пристрій для подачі звукового сигналу водію транспортного засобу (рис. 1) (Sydor, 2018).

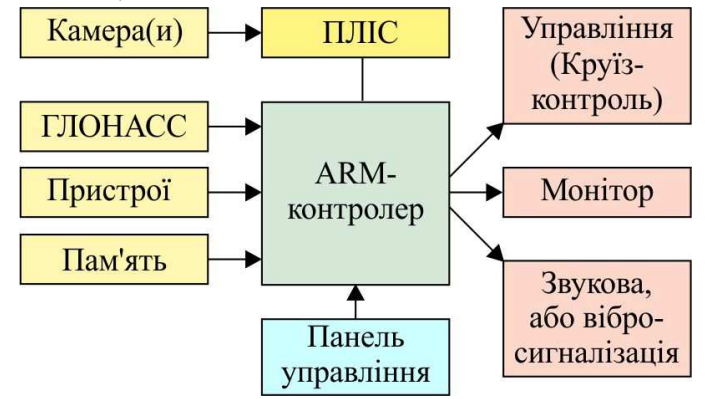

Рис. 1. Структурна схема системи розпізнавання дорожніх знаків

Алгоритм роботи електронного блоку керування такий:

\section{Інформація про авторів:}

Сидор Андрій Іванович, аспірант, кафедра спеціалізованих комп'ютерних систем. Email: andrij9997@ukr.net Цитування за Дсту: Сидор А. І. Метод розпізнавання дорожніх знаків на основі оцінок Хеммінгової віддалі та структурної складності. Науковий вісник НлтУ України. 2018, т. 28, № 7. С. 120-125.

Citation APA: Sydor, A. I. (2018). The method of road signs recognition based on the evaluation of the Hamming distance and structural complexity. Scientific Bulletin of UNFU, 28(7), 120-125. https://doi.org/10.15421/40280725 
1. Визначення місця розміщення дорожнього знаку;

2. Визначення форми дорожнього знаку;

3. Визначення кольору знаку;

4. Аналіз напису на знаку;

5. Опрацювання отриманої інформації;

6. Отримання інформації про швидкість автомобіля;

7. Порівняння швидкості автомобіля 3 дозволеною швидкістю

8. Вивід зображення дорожнього знаку на екран;

Повідомлення водія звуковим сигналом про перевищення швидкості.

Дорожні знаки є об'єктом структурної ідентифікації, що дасть змогу узагальнити та істотно вдосконалити математику формування, передавання та цифрового опрацювання даних у розподілених комп'ютерних системax.

Мета роботи - проаналізувати складність дорожніх знаків на основі оцінки структурної складності, яку запропонувала Возна Н. Я. (Vozna, 2015), а також визначити оцінку Хеммінгової віддалі для категорії наказові та заборонні знаки (Vozna, 2011).

Категорія наказових знаків. Поряд з оцінкою Хеммінгової віддалі (Krulikovskyi et al., 2017) (формула 1), визначимо коефіцієнт структурної складності (формула 2) груп дорожніх знаків:

$$
d_{i j}=\sum_{i, j=1}^{n} e_{i}\left|x_{i}-x_{j}\right|, j=\overline{1, n}, i=\overline{1, m} ;
$$

$$
k_{c}=\sum_{i=1}^{n} \alpha_{i} P_{i},
$$

де: $x_{i}, x_{j}$ - кодовані атрибути масивів даних, які представляють об'єкти, що підлягають розпізнаванню згідно 3 оцінкою Хеммінгової віддалі (Nykolaichuk et al., 2017); $e_{i}-$ ваговий коефіцієнт інформативності пари атрибутів образів, що розпізнаються; $j \in n, i \in m, n-$ кількість пар атрибутів у вузлі Хеммінгового простору (ХП); $d_{i i}$ - числова оцінка Хеммінгової віддалі, представлена у кодах відповідного ТЧБ (Krulikovskyi et al., 2017); $\alpha_{i}$ - коефіцієнт складності компонентів атрибутів поліфункціональних даних; $P_{i}$-вагові коефіцієнти оцінок інформативності їх параметрів. Запропонований у роботах (Vozna, 2011, 2015; Vozna, \& Sydor, 2017) критерій структурної складності, розроблений на основі вагових коефіцієнтів оцінок інформативності, дає змогу інтегрально оцінити структурну складність та інформаційну цінність будь-якого графічного зображення, що $є$ необхідним для розвитку сучасних методів та засобів ідентифікації, перетворення та використання поліфункціональних інформаційних повідомлень (Nykolaichuk et al., 2017).

Однією 3 найважливіших категорій із розпізнавання дорожніх знаків $є$ категорія наказових знаків (рис. 2).
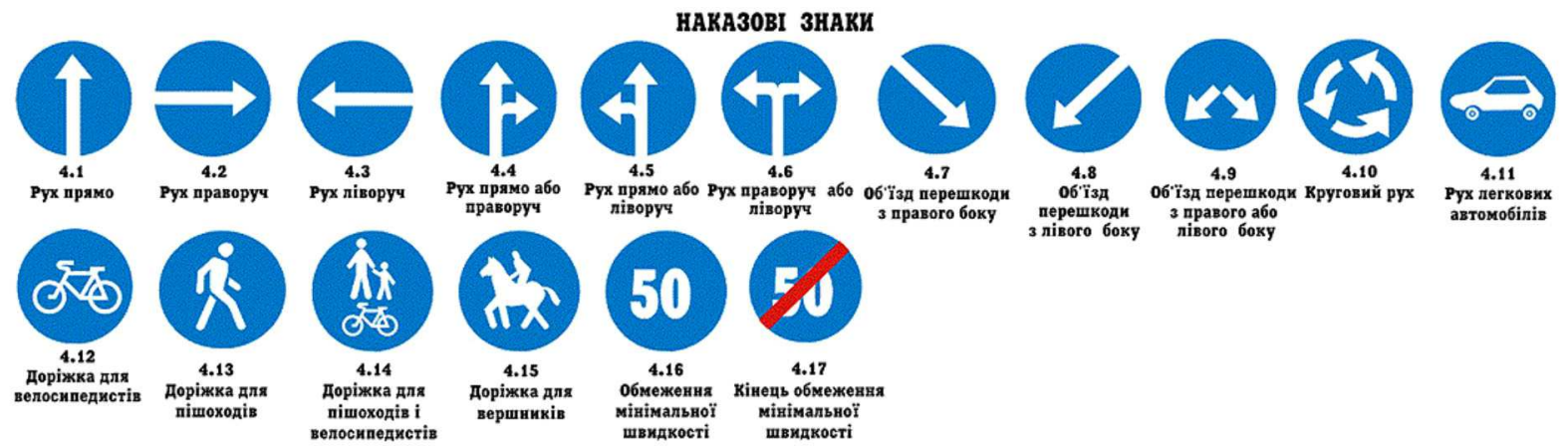

Рис. 2. Наказові знаки

Розробку методу розпізнавання дорожніх знаків виконаємо шляхом розбиття категорії наказові на дві менші підкатегорії: наказові знаки зі стрілкою (НЗС) і наказові знаки без стрілки (НЗБ). До групи НЗС ввійдуть знаки з такими номерами: 4.1, 4.2, 4.3, 4.4, 4.5, 4.6, 4.7, $4.8,4.9,4.10$. До групи НЗБ входять знаки з такими номерами: 4.11, 4.12, 4.13, 4.14, 4.15, 4.16, 4.17.

Категорія НЗС. Для кодування цієї категорії використаємо 4-бітне кодування елементів: перший біт знаки, на яких стрілка напрямлена вгору; другий біт знаки, на яких стрілка напрямлена вниз; третій біт знаки, на яких стрілка напрямлена вліво; четвертий біт - знаки, на яких стрілка напрямлена вправо. Тоді отримаємо такі коди для знаків групи НЗС та оцінки їх структурної складності (табл. 1):

Табл. 1. Закодовані параметри категорії НЗС

\begin{tabular}{|c|c|c|c|c|c|}
\hline $\begin{array}{c}\text { Номер } \\
\text { знаку }\end{array}$ & $\begin{array}{c}\text { Код } \\
\text { знаку }\end{array}$ & $\begin{array}{c}\text { Структурна } \\
\text { скадність }\left(k_{c}\right)\end{array}$ & $\begin{array}{c}\text { Номер } \\
\text { знаку }\end{array}$ & $\begin{array}{c}\text { Код } \\
\text { знаку }\end{array}$ & $\begin{array}{c}\text { Структурна } \\
\text { складність } \\
\left(k_{c}\right)\end{array}$ \\
\hline 4.1 & 1000 & 14,2 & 4.6 & 0011 & 19,2 \\
\hline 4.2 & 0001 & 14,2 & 4.7 & 0101 & 14,2 \\
\hline 4.3 & 0010 & 14,2 & 4.8 & 0110 & 14,2 \\
\hline 4.4 & 1001 & 19,2 & 4.9 & 0111 & 17,2 \\
\hline 4.5 & 1010 & 19,2 & 4.10 & 1111 & 20,8 \\
\hline
\end{tabular}

Отримані значення оцінок Хеммінгової віддалі згідно $з$ формулою наведено в табл. 2.

Табл. 2. Значення оцінок Хеммінгової віддалі для категорії Н3С

\begin{tabular}{|c|c|c|c|c|c|c|c|c|c|c|}
\hline № & 4.1 & 4.2 & 4.3 & 4.4 & 4.5 & 4.6 & 4.7 & 4.8 & 4.9 & 4.10 \\
\hline 4.1 & - & 9 & 10 & 1 & 2 & 11 & 13 & 14 & 15 & 7 \\
\hline 4.2 & 9 & - & 3 & 8 & 11 & 2 & 4 & 7 & 6 & 14 \\
\hline 4.3 & 10 & 3 & - & 11 & 8 & 1 & 7 & 4 & 5 & 13 \\
\hline 4.4 & 1 & 8 & 11 & - & 3 & 10 & 12 & 15 & 14 & 6 \\
\hline 4.5 & 2 & 11 & 8 & 3 & - & 9 & 15 & 12 & 13 & 5 \\
\hline 4.6 & 11 & 2 & 1 & 10 & 9 & - & 6 & 5 & 4 & 12 \\
\hline 4.7 & 13 & 4 & 7 & 12 & 15 & 6 & - & 3 & 2 & 10 \\
\hline 4.8 & 14 & 7 & 4 & 15 & 12 & 5 & 3 & - & 1 & 9 \\
\hline 4.9 & 15 & 6 & 5 & 14 & 13 & 4 & 2 & 1 & - & 8 \\
\hline 4.10 & 7 & 14 & 13 & 6 & 5 & 12 & 10 & 9 & 8 & - \\
\hline
\end{tabular}

Розподіл значень оцінки Хеммінгової віддалі наведено на діаграмі (рис. 3):

На діаграмі зображено розподіл оцінок Хеммінгової віддалі залежно від отриманих значень. По вертикалі показано, яка кількість пар знаків порівняння має вказані значення оцінок Хеммінгової віддалі. 3 рис. 3 видно, що є 15 пар знаків, які мають значення Хеммінгової віддалі від 1 до 5, 9, пар знаків - від 6 до 8, 12 пар знаків від 9 до 12 і 9 пар знаків має значення - від 12 до 15. На інших діаграмах розподілу застосовується подібний принцип. 


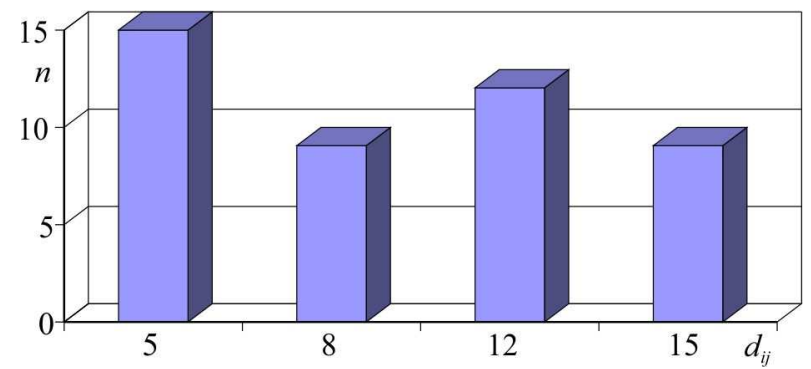

Рис. 3. Діаграма розподілу значень Хеммінгової віддалі для категорії Н3С
Отже, для кожного знаку можна побудувати характеристику середньостатистичної оцінки інформативності знакового символу відносно інших знаків цієї категорії згідно з формулою:

$$
I_{i j}=\frac{d_{i j}}{k_{c i}+k_{c j}}, j=\overline{1, n}, i=\overline{1, m} .
$$

Оцінку інформативності для категорії НЗС наведено в табл. 3, графіки отриманих результатів відображено на рис. 4.

Табл. 3. Значення оцінок інформативності для категорії НЗС

\begin{tabular}{|c|c|c|c|c|c|c|c|c|c|c|}
\hline № & 4.1 & 4.2 & 4.3 & 4.4 & 4.5 & 4.6 & 4.7 & 4.8 & 4.9 & 4.10 \\
\hline 4.1 & - & 0,32 & 0,35 & 0,03 & 0,06 & 0,33 & 0,46 & 0,49 & 0,48 & 0,20 \\
\hline 4.2 & 0,32 & - & 0,11 & 0,24 & 0,33 & 0,06 & 0,14 & 0,25 & 0,19 & 0,40 \\
\hline 4.3 & 0,35 & 0,11 & - & 0,33 & 0,24 & 0,03 & 0,25 & 0,14 & 0,16 & 0,37 \\
\hline 4.4 & 0,03 & 0,24 & 0,33 & - & 0,08 & 0,26 & 0,36 & 0,45 & 0,38 & 0,15 \\
\hline 4.5 & 0,06 & 0,33 & 0,24 & 0,08 & - & 0,23 & 0,45 & 0,36 & 0,36 & 0,13 \\
\hline 4.6 & 0,33 & 0,06 & 0,03 & 0,26 & 0,23 & - & 0,18 & 0,15 & 0,11 & 0,30 \\
\hline 4.7 & 0,46 & 0,14 & 0,25 & 0,36 & 0,45 & 0,18 & - & 0,11 & 0,06 & 0,29 \\
\hline 4.8 & 0,49 & 0,25 & 0,14 & 0,45 & 0,36 & 0,15 & 0,11 & - & 0,03 & 0,26 \\
\hline 4.9 & 0,48 & 0,19 & 0,16 & 0,38 & 0,36 & 0,11 & 0,06 & 0,03 & - & 0,21 \\
\hline 4.10 & 0,20 & 0,40 & 0,37 & 0,15 & 0,13 & 0,30 & 0,29 & 0,26 & 0,21 & $-!$ \\
\hline
\end{tabular}

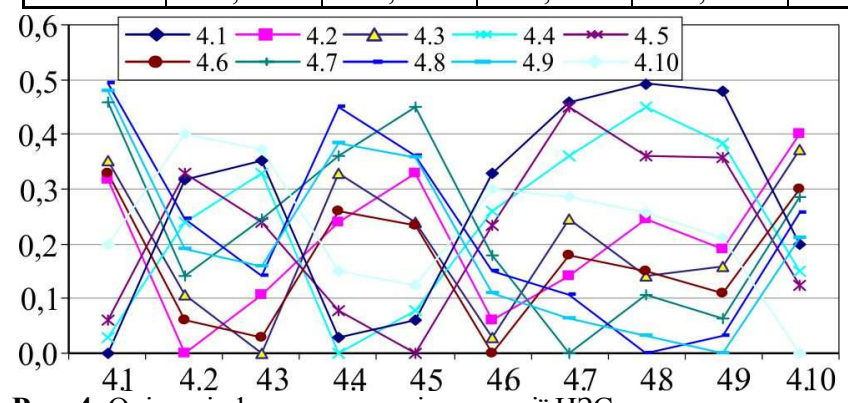

Рис. 4. Оцінка інформативності категорії НЗС

Аналіз отриманих результатів дає змогу зробити такі висновки:

1) мінімальна Хеммінгова віддаль для цієї категорії знаків становить не менше оцінки 5;

2) максимальне значення для повного набору бази ідентифікації цієї категорії знаків становить не більше оцінки 15.

Категорія НЗБ. Для кодування цієї категорії використаємо 5-бітне кодування елементів: перший бітзнаки, на яких зображена цифра (ця група потребує окремого розпізнавання значень); другий біт - знаки, на яких зображено людину; третій біт - знаки, на яких зображено велосипед; четвертий біт - знаки, на яких зображено коня; п'ятий біт - знаки, на яких є червона лінія. Отже, отримаємо такі коди для знаків групи НЗБ (табл. 4):

Табл. 4. Закодовані параметри категорії НЗБ

\begin{tabular}{|c|c|c|c|c|c|}
\hline $\begin{array}{c}\text { Номер } \\
\text { знаку }\end{array}$ & $\begin{array}{c}\text { Код } \\
\text { знаку }\end{array}$ & $\begin{array}{c}\text { Структурна } \\
\text { складність } \\
\left(k_{c}\right)\end{array}$ & $\begin{array}{c}\text { Номер } \\
\text { знаку }\end{array}$ & $\begin{array}{c}\text { Код } \\
\text { знаку }\end{array}$ & $\begin{array}{c}\text { Структурна } \\
\text { складність } \\
\left(k_{c}\right)\end{array}$ \\
\hline 4.11 & 00000 & 21,2 & 4.15 & 01010 & 31.2 \\
\hline 4.12 & 00100 & 21.2 & 4.16 & 10000 & 19,2 \\
\hline 4.13 & 01000 & 21.2 & 4.17 & 10001 & 20,2 \\
\hline 4.14 & 01100 & 41,2 & & & \\
\hline
\end{tabular}

Графік оцінок інформативності для категорії НЗБ зображено на рис. 5 .

Розподіл значень оцінки Хеммінгової віддалі для категорії НЗБ наведено в діаграмі (рис. 6).

Аналіз отриманих результатів дає змогу зробити такі висновки:

1) мінімальна Хеммінгова віддаль для цієї категорії знаків становить не менше оцінки 4;
2) максимальне значення для повного набору бази ідентифікації цієї категорії знаків становить не більше оцінки 29.

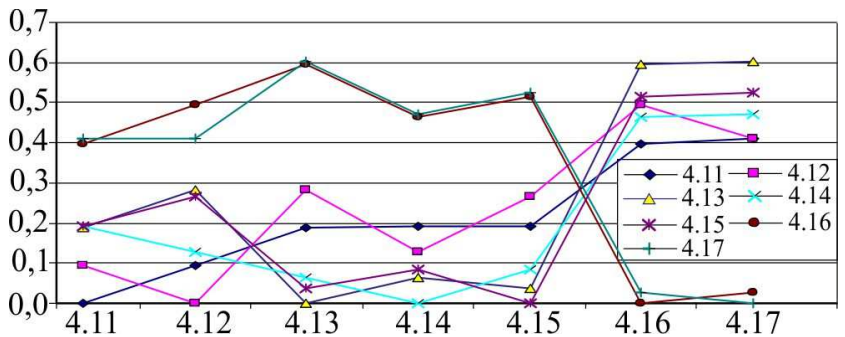

Рис. 5. Оцінка інформативності категорії НЗБ

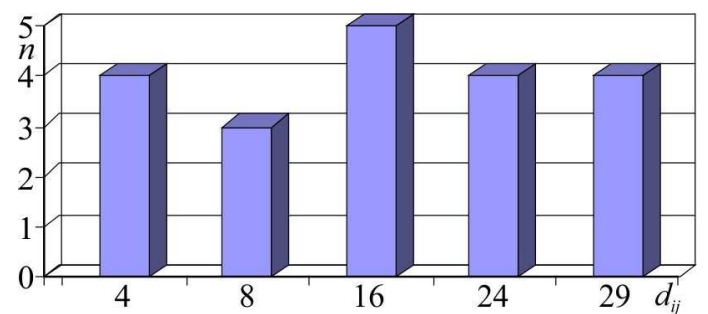

Рис. 6. Діаграма розподілу значень Хеммінгової віддалі для категорії НЗБ

Категорія заборонних знаків. Ще однією важливою категорією є категорія заборонних знаків (рис. 7).

Для більшої зручності цю категорію доцільно поділити на три менші підкатегорії, виконавши 2-бітне кодування: перший біт - кодує наявність цифр на зображенні дорожнього знаку; другий біт - кодує наявність на зображеннях дорожніх знаків кольорів, крім чорного, червоного і білого. Виконавши таке кодування, отримаємо такі категорії з кодами: заборонні знаки з цифрами (ЗЗЦ) код 10, заборонні знаки 3 додатковими кольорами (З3К) код 01, заборонні знаки решта (З3Р) код 00 .

До групи ЗЗЦ входять відповідні знаки з такими номерами: $3.3,3.15,3.16,1.17,3.18,3.19,3.20,3.29,3.30$, $3.31,3.32$.

До групи З3К входять знаки 3 такими номерами: 3.12, 3.13, 3.14, 3.34, 3.35, 3.36, 3.37, 3.38, 3.39.

До групи ЗЗР входять знаки з такими номерами: 3.1 , 3.2, 3.4, 3.5, 3.6, 3.7, 3.8, 3.9, 3.10, 3.11, 3.21, 3.22, 3.23, $3.24,3.25,3.26,3.27,3.28,3.33,3.40,3.41,3.42$. 3.43. 


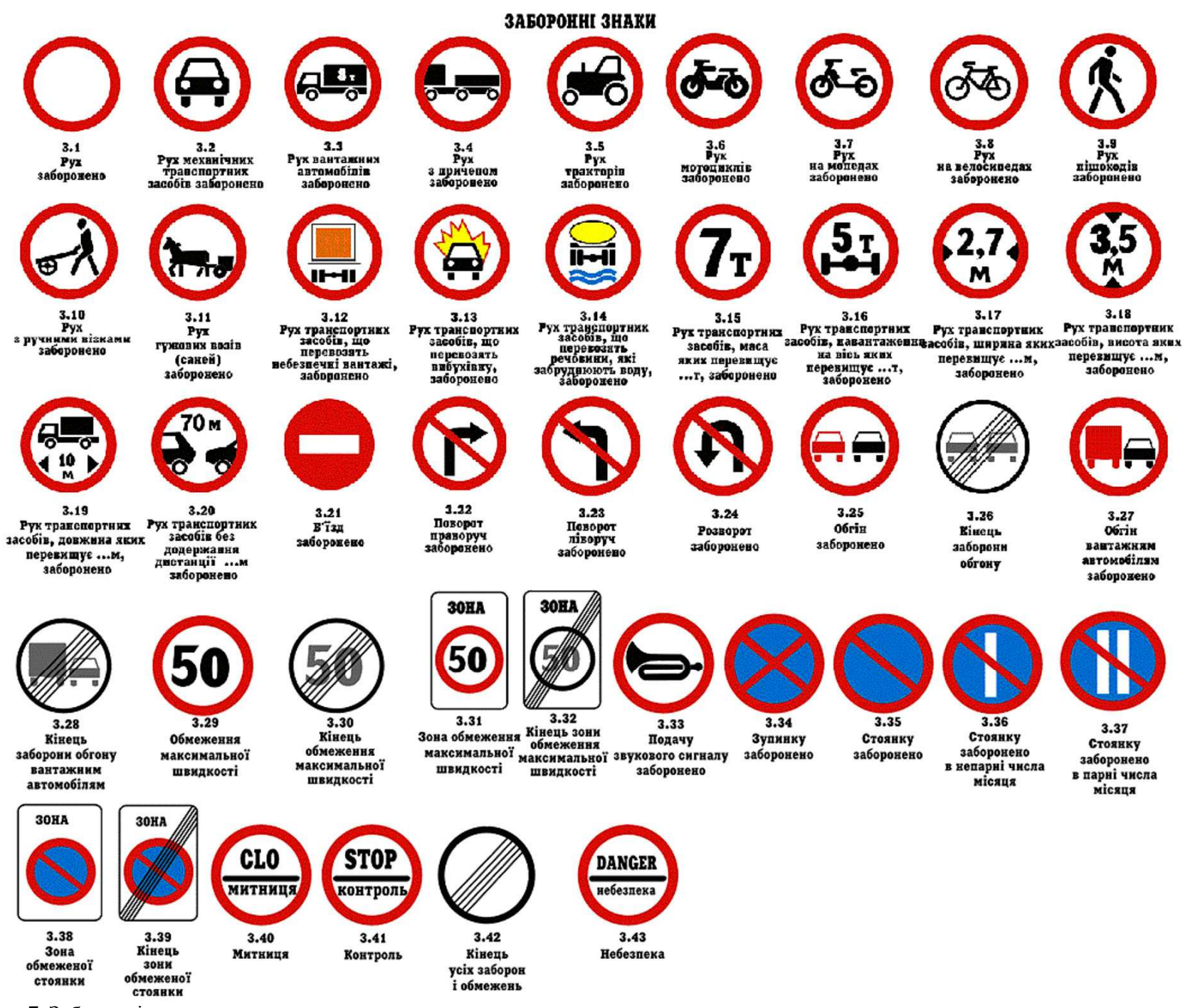

Рис. 7. Заборонні знаки

Табл. 5. Закодовані параметри заборонних знаків

\begin{tabular}{|c|c|c|c|c|c|}
\hline Номер знаку & Код знаку & Структурна складність $\left(k_{c}\right)$ & Номер знаку & Код знаку & Структурна складність $\left(k_{c}\right)$ \\
\hline 3.3 & 0100011 & 11,2 & 3.20 & 0011111 & 37,2 \\
\hline 3.15 & 0101100 & 13,2 & 3.29 & 0001100 & 9,2 \\
\hline 3.16 & 0101101 & 23,2 & 3.30 & 0000001 & 14,2 \\
\hline 3.17 & 0011101 & 23,2 & 3.31 & 1001001 & 51 \\
\hline 3.18 & 0011001 & 23,2 & 3.32 & 1000001 & 86 \\
\hline 3.19 & 0011011 & 31,2 & & & \\
\hline
\end{tabular}

Розглянемо детальніше кожну 3 підкатегорій, шляхом кодування їхніх елементів та обчислення оцінки Хеммінгової віддалі.

Категорія 3ЗЦ. Для кодування цієї категорії використаємо 7-бітне кодування елементів із додатково введеними спеціальними трьома бітами: перший біт - знаки, які мають квадратну форму; другий біт - знаки, які мають на своєму фоні букву "т"; третій біт - знаки, які мають на своєму фоні букву "м"; четвертий біт - знаки, на яких розміщені чорні цифри; п'ятий біт - знаки, на яких цифри розміщені нижче від малюнка; шостий біт знаки із зображенням автомобіля; сьомий біт - знаки, на яких, окрім цифр і букв, є ще інші зображення; додатково введені три біти відповідатимуть за код значення цифри, зображеної на дорожньому знакові й необхідні для точнішої ідентифікації.

Тоді отримаємо такі коди для знаків групи ЗЗЦ (табл. 5).

Графік оцінок інформативності для категорії ЗЗЦ зображено на рис. 8.

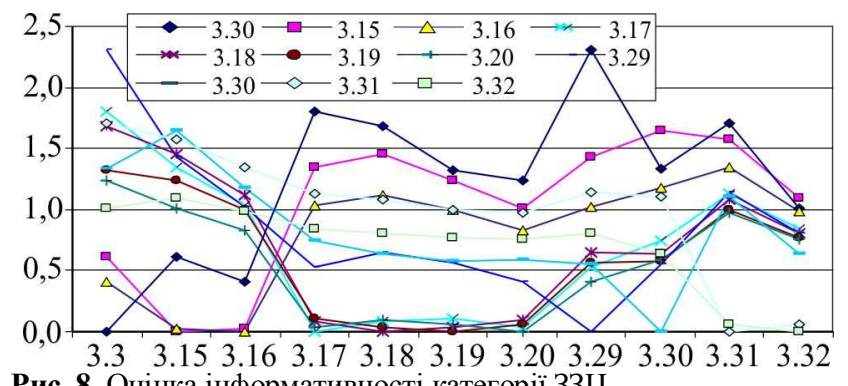

Рис. 8. Оцінка інформативності категорії ЗЗЦ

Розподіл значень оцінки Хеммінгової віддалі наведено на діаграмі (рис. 9, $a$ ).

Аналіз отриманих результатів дає змогу зробити такі висновки:

1) мінімальна Хеммінгова віддаль для цієї категорії знаків становить не менше оцінки 14;

2) максимальне значення для повного набору бази ідентифікації цієї категорії знаків становить не більше оцінки 109. 

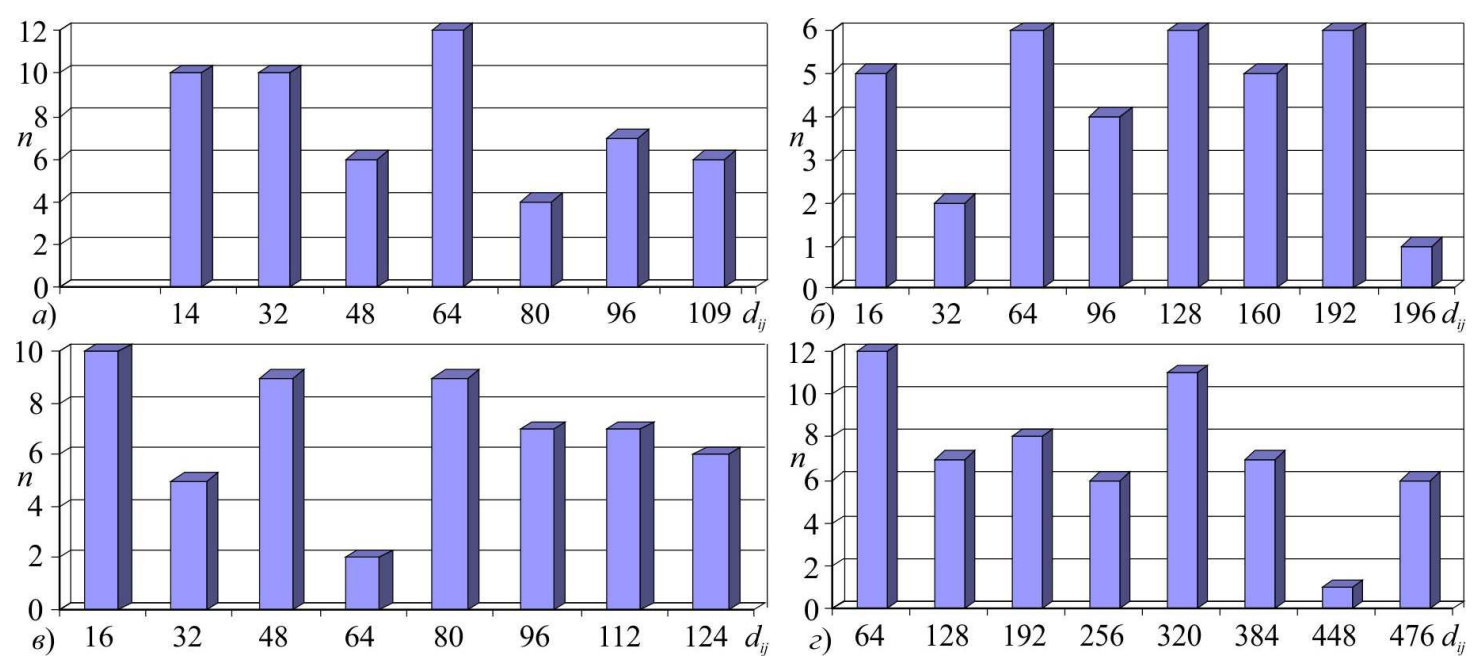

Рис. 9. Діаграма розподілу значень Хеммінгової віддалі для категорії: а) ЗЗЦ; б) ЗЗК; в) ЗЗРТ; г) ЗЗРБ

Категорія 33К. Для кодування цієї категорії використаємо 8-бітне кодування елементів: перший біт знаки, які мають круглу форму; другий біт - знаки, які мають білий колір; третій біт - знаки, які мають червоний колір; четвертий біт - знаки, які мають жовтий колір; п'ятий біт - знаки із зображенням автомобіля; шостий біт - знаки із чотирма чорними лініями; сьомий біт - знаки із перетином червоних ліній; восьмий біт знаки, які мають 2 білі прямокутники (червона лінія ігнорується). Тоді отримаємо такі коди для знаків групи З3К (табл. 6):

Розподіл значень оцінок Хеммінгової віддалі наведено на діаграмі (рис. 9,б).

Аналіз отриманих результатів дає змогу зробити такі висновки:

1) мінімальна Хеммінгова віддаль для цієї категорії знаків становить не менше оцінки 16;

2) максимальне значення для повного набору бази ідентифікації цієї категорії знаків становить не більше оцінки 196.

Категорія 33Р. Для більшої зручності цю категорію можна поділити на 2 менші підкатегорії - заборонні знаки із транспортом (З3РТ) і заборонні знаки без транспорту (ЗЗРБ). До групи ЗЗРТ ввійдуть знаки з такими номерами: 3.2, 3.4, 3.5, 3.6, 3.7, 3.8, 3.11, 3.25, 3.26, 3.27,
3.28. До групи ЗЗРБ ввійдуть знаки з такими номерами: $3.1,3.9,3.10,3.21,3.22,3.23,3.24,3.33,3.40,3.41,3.42$, 3.43. Для кодування категорії 3ЗРТ використаємо 7-бітне кодування елементів: перший біт - знаки, на яких зображено легковий автомобіль; другий біт - знаки, на яких зображено причеп; третій біт - знаки, які мають транспорт червоного кольору; четвертий біт - знаки, які мають на своєму фоні два елементи; п'ятий біт - знаки iз зображенням механічного транспорту; шостий біт знаки, на яких зображено трактор; сьомий біт - знаки, на яких зображено мопед. Для кодування категорії ЗЗРБ використаємо 9-бітне кодування елементів: перший біт - знаки із чорними лініями; другий біт - знаки із червоними лініями; третій біт - знаки, які мають тільки два кольори; четвертий біт - знаки, які мають на своєму фоні чорні круги; п'ятий біт і шостий біт позначимо через 00 - знаки без стрілок, 10 - стрілка вліво, 01 - стрілка вправо, 11 - стрілка вниз; сьомий біт - знаки, на яких зображено білий прямокутник; восьмий біт - знаки, на яких зображено букву "S"; дев'ятий біт - знаки, на яких зображено візок.

Тоді отримаємо такі коди для знаків групи З3РТ (табл. 7), а також коди для знаків групи З3РБ (табл. 8).

Табл. 6. Закодовані параметри категорії З3К

\begin{tabular}{|c|c|c|c|c|c|}
\hline Номер знаку & Код знаку & Номер знаку & Код знаку & Номер знаку & Код знаку \\
\hline 3.12 & 11000000 & 3.34 & 10100010 & 3.37 & 11100001 \\
\hline 3.13 & 11011000 & 3.35 & 10100000 & 3.38 & 01100000 \\
\hline 3.14 & 11010000 & 3.36 & 11100000 & 3.39 & 01100100 \\
\hline
\end{tabular}

Табл. 7. Закодовані параметри категорії 3ЗРТ

\begin{tabular}{|c|c|c|c|c|c|}
\hline Номер знаку & Код знаку & Номер знаку & Код знаку & Номер знаку & Код знаку \\
\hline 3.2 & 1000000 & 3.7 & 0000001 & 3.26 & 1001000 \\
\hline 3.4 & 0100000 & 3.8 & 0000100 & 3.27 & 1111000 \\
\hline 3.5 & 0000010 & 3.11 & 0100100 & 3.28 & 1101000 \\
\hline 3.6 & 0000000 & 3.25 & 1011000 & & \\
\hline
\end{tabular}

Табл. 8. Закодовані параметри категорії ЗЗРБ

\begin{tabular}{|c|c|c|c|c|c|}
\hline Номер знаку & Код знаку & Номер знаку & Код знаку & Номер знаку & Код знаку \\
\hline 3.1 & 001000000 & 3.22 & 110001000 & 3.40 & 100100000 \\
\hline 3.9 & 000100000 & 3.23 & 110010000 & 3.41 & 100100010 \\
\hline 3.10 & 000100001 & 3.24 & 110011000 & 3.42 & 101100000 \\
\hline 3.21 & 001000100 & 3.33 & 000000000 & 3.43 & 100000000 \\
\hline
\end{tabular}

Розподіл значень оцінок Хеммінгової віддалі для категорій ЗЗРТ та ЗЗРБ наведено на діаграмах (рис. 9,6 та 9,2).

Аналіз отриманих результатів дає змогу зробити такі висновки:
1) мінімальна Хеммінгова віддаль для цих категорії знаків становить не менше оцінки 16 і 64 відповідно;

2) максимальне значення для повного набору бази ідентифікації цих категорій знаків становить не більше оцінки 124 і 476 відповідно. 
Висновок. Отже, розглянуто основні принципи роботи систем із розпізнавання дорожніх знаків. Проаналізовано дорожні знаки категорії наказові та забороні дорожні знаки, запропоновано розбиття системи знаків на менші підкатегорії на основі групованих елементів зображень. Запропоновано метод кодування і знаходження Хеммінгової віддалі для дорожніх знаків категорії наказові знаки та забороні знаки. Обчислено структурну складність знаків цих категорій. Визначено коефіцієнт інформативності, на основі якого можна запропонувати рекомендації із покращення зображень дорожніх знаків, для якіснішого комп'ютиризованого розпізнавання.

\section{Перелік використаних джерел}

Krulikovskyi, B., Sydor, A., Zastavnyy, O., \& Nykolaichuk, Y. (2017). Method for Multidimensional Patterns Recognition in Hamming Spase. CADSM'2017, (pp. 195-198). Lviv, Ukraina.

Nykolaichuk, Ya. M. (Ed.), Pastukh, T. I., Pitukh, I. R., Sehin, A. I., et al. (2017). Spetsializovani kompiuterni tekhnolohii v informatytsi. Ternopil: Beskydy, 919 p. [In Ukrainian].
Sehin, A. I. (2013). Spetsializovana kompiuterna systema rozpiznavannia dorozhnikh znakiv $\mathrm{v}$ rezhymi realnoho chasu dlia transportnykh zasobiv. Visnyk Khmelnytskoho natsionalnoho universytetu, 6, 230-235. [In Ukrainian].

Sydor, A. I. (2018). Metod rozpiznavannia dorozhnikh znakiv katehorii "poperedzhuvalni znaky" na osnovi otsinok Khemminhovoi viddali ta strukturnoi skladnosti. Yurysprudentsiia ta problemy informatsiinoho suspilstva: materialy problemno-naukovoi mizhhaluzevoi konferentsii, (pp. 140-146). Nadvirna, May 23-25. [In Ukrainian].

Vozna, N. Ya (2011). Teoriia ta otsinka informatyvnosti strukturovanykh hrafichnykh ta videozobrazhen. Yurysprudentsiia ta problemy informatsiinoho suspilstva: zbirnyk materialiv problemnonaukovoi mizhhaluzevoi konferentsii, (pp. 65-70). Ivano-Frankivsk. [In Ukrainian].

Vozna, N. Ya. (2015). Osnovy teorii strukturyzatsii polifunktsionalnykh elementiv skladnykh system. Visnyk Khmelnytskoho natsionalnoho universytetu, 2(223), 204-208. [In Ukrainian].

Vozna, N. Ya., \& Sydor, A. I. (2017). Kryterii strukturnoi skladnosti ta otsinky rozshyrenoi Khemminhovoi viddali dlia prostorovykh obiektiv. Scientific Bulletin of UNFU, 27(4), 159-165. [In Ukrainian].

Тернопольский национальный экономический университет, г. Тернополь, Украина

\section{МЕТОД РАСПОЗНАВАНИЯ ДОРОЖНЫХ ЗНАКОВ НА ОСНОВЕ ОЦЕНОК ХЕММИНГОВОГО РАССТОЯНИЯ И СТРУКТУРНОЙ СЛОЖНОСТИ}

Проанализированы основные принципы работы систем распознавания дорожных знаков известных производителей. Описан алгоритм работы и основные компоненты устройства определения элементов, изображенных на дорожном знаке. Предложен метод распознавания дорожных знаков на основе оценки Хеммингового расстояния. Проведен анализ дорожных знаков категории указательные знаки. Осуществлено разбиение данной категории на меньшие подкатегории для качественного анализа изображений. Выделены основные элементы указательных знаков, на основе которых предложено кодирования для каждого знака данной категории. Рассчитана структурная сложность изображений дорожных знаков категории указательные знаки. Приведена таблица значений оценок Хеммингового расстояния для различных пар знаков предложенных подкатегорий, на основе которых построены диаграммы распределения значений оценок Хеммингового расстояния. Проведен анализ дорожных знаков категории запрещающие знаки. Для данной категории определены меньше подкатегории, предложено кодирование знаков, основанное на качественных признаках изображенных элементов, построены диаграммы распределения значений полученных оценок Хеммингового расстояния. Для рассмотренных категории знаков вычислено максимальные и минимальные значения Хеммингового расстояния. Предложенная оценка информативности дорожных знаков, которая основана на отношении Хеммингового расстоянии к структурной сложности. Построенные графики, наглядно иллюстрируют информативность рассмотренных знаков каждой из подкатегорий.

Ключевые слова: оценка информативности; системы распознавания; структурная идентификация; кодирование.

A. I. Sydor
Ternopil National Economic University, Ternopil, Ukraine

THE METHOD OF ROAD SIGNS RECOGNITION BASED ON THE EVALUATION OF THE HAMMING DISTANCE AND STRUCTURAL COMPLEXITY

Due to the increase in the number and dynamics of traffic flows, the task of automatic recognition of road signs becomes urgent. This is necessary to reduce the number of road traffic accidents and environmental pollution. This task is especially relevant when there is a barrier to perception and correct recognition of signs in conditions of fog, rain, dust etc. The development of the proposed method is based on the analysis of road signs images, definition of Hamming distance, structural complexity and information coding of road signs. Tables and charts based on the obtained results were constructed. Estimates of informativeness of the considered road signs were calculated. The obtained results are illustrated on the charts. The components of road signs recognition systems were classified. The basic principles of the control element operation of road signs recognition systems of well-known manufacturers were described. Prohibitive and prescriptive road signs were investigated in the work. These categories were divided into smaller subcategories. The criterion of division was the analysis of road signs features. Code values for signs of each of subcategories were offered. The values of Hamming distance estimation and structural complexity were calculated. The maximum and minimum values of the Hamming distance estimates for the signs of each of the subcategories were calculated. The analytical expression for finding the evaluation of the informativity of the road sign was obtained. Such an analytical expression is obtained on the basis of the ratio of the Hamming distance to the structural complexity. Estimates of informativity for the categories of marks considered were calculated. Charts illustrating informativity estimates for pairs of signs of the subcategories under consideration were constructed. Recommendations for the improvement of road sign images, for better computerized recognition based on the received results were proposed.

Keywords: informativity estimates; recognition system; structural identification; coding. 